Supporting Information:

\title{
Probing Chemical Shifts of Invisible States of Proteins with Relaxation Dispersion NMR Spectroscopy: How Well Can We Do?
}

D. Flemming Hansen, Pramodh Vallurupalli, Patrik Lundström, Philipp Neudecker and Lewis E. Kay

Figure S1:

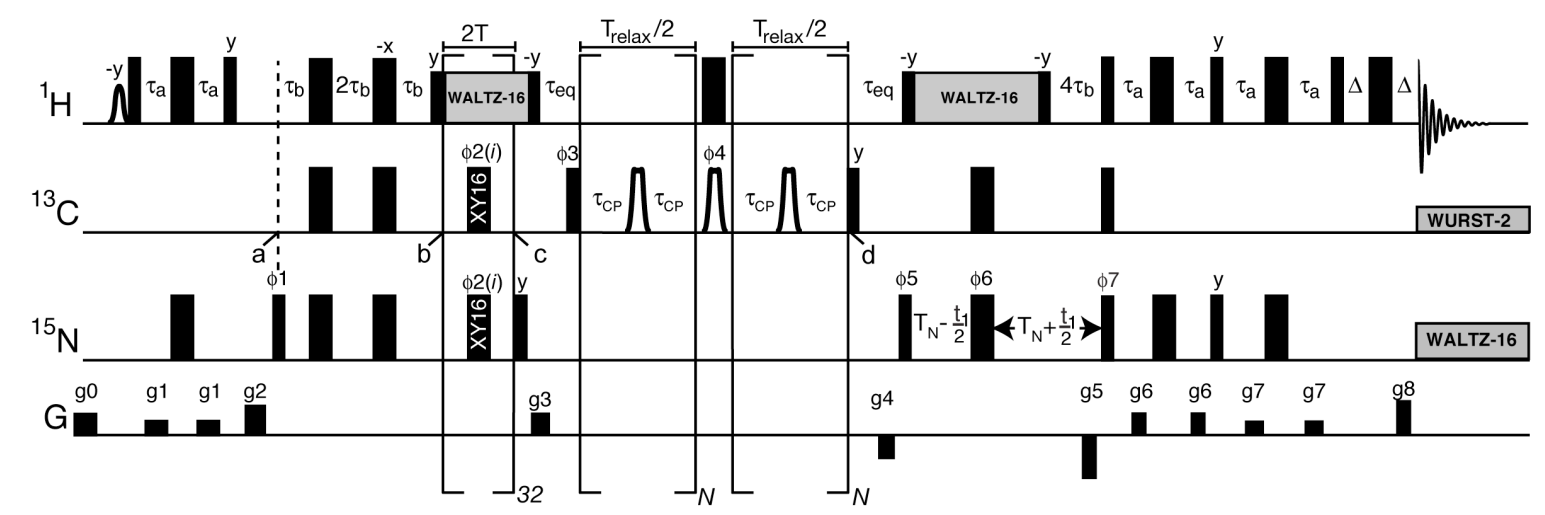

Pulse scheme of the ${ }^{13} \mathrm{CO}$ constant-time relaxation dispersion experiment for measuring millisecond time-scale dynamics in ${ }^{15} \mathrm{~N}$-, ${ }^{13} \mathrm{CO}$-labeled proteins. ${ }^{1} \mathrm{H},{ }^{13} \mathrm{C}$, and ${ }^{15} \mathrm{~N} 90^{\circ}\left(180^{\circ}\right)$ rf pulses are shown as narrow (wide) black bars; ${ }^{1} \mathrm{H}$ and ${ }^{15} \mathrm{~N}$ pulses are applied at the highest possible power level, while ${ }^{13} \mathrm{C}$ pulses (both those that are rectangular and the shaped RE-BURP ${ }^{1}$ pulses during the CPMG element between points $c$ and $d$ ) are applied with a $16 \mathrm{kHz}$ field. The use of $\mathrm{CO}$-selective pulses during the $\mathrm{CPMG}$ element refocuses small (2 or more bond) CO-aliphatic carbon couplings that arise from the labeling scheme employed. The shaped $90^{\circ}{ }^{1} \mathrm{H}$ pulse of phase $-\mathrm{y}$ is water-selective ( 1.6 ms rectangular pulse). All pulse phases are assumed to be $\mathrm{x}$, unless indicated otherwise. The ${ }^{1} \mathrm{H}$ carrier is placed on the water signal, while the ${ }^{13} \mathrm{C}$ and ${ }^{15} \mathrm{~N}$ rf carriers are at 175 and $119 \mathrm{ppm}$, 
respectively. Magnetization transfer from ${ }^{15} \mathrm{~N}$ to ${ }^{13} \mathrm{CO}$ occurs from $a$ to $c$; from $a$ to $b$ $\left(0.5 / \mathrm{J}_{\mathrm{NH}}\right){ }^{15} \mathrm{~N}$ magnetization is refocused with respect to ${ }^{1} \mathrm{H}$ and dephased with respect to ${ }^{13} \mathrm{CO}$. Subsequently, from $b$ to $c,{ }^{15} \mathrm{~N}$ evolution with respect to the one-bond ${ }^{15} \mathrm{~N}-{ }^{13} \mathrm{CO}$ scalar coupling continues through the application of simultaneous ${ }^{13} \mathrm{C}$ and ${ }^{15} \mathrm{~N}$ pulses at a frequency of $800 \mathrm{~Hz}$. This scheme quenches chemical exchange that occurs on time-scales slower than $\sim 1 / 800 \mathrm{~Hz} \sim 1.3 \mathrm{~ms}$ leading to improvements in sensitivity ${ }^{2,3}$. Each of the simultaneous 32 pulses labeled XY 16 has phase $\phi 2(i)=2\{\mathrm{x}, \mathrm{y}, \mathrm{x}, \mathrm{y}, \mathrm{y}, \mathrm{x}, \mathrm{y}, \mathrm{x},-\mathrm{x},-\mathrm{y},-\mathrm{x},-\mathrm{y},-\mathrm{y},-\mathrm{x},-\mathrm{y},-\mathrm{x}\}^{4}($ i.e., pulse 1 is phase $\mathrm{x}$, pulse 2 phase $\mathrm{y}$, pulse 3 phase $\mathrm{x}$, etc.) so that both the $\mathrm{x}$ and the $\mathrm{y}$ components of transverse magnetization are refocused properly in the presence of off-resonance effects and pulse imperfections. ${ }^{1} \mathrm{H}$ decoupling during the ${ }^{15} \mathrm{~N}-->{ }^{13} \mathrm{CO}$ transfer and during $\mathrm{t}_{1}$ is achieved with a WALTZ-16 scheme ${ }^{5}$ applied at a field of $6 \mathrm{kHz} .{ }^{15} \mathrm{~N}$ decoupling during acquisition is achieved with a $1.5 \mathrm{kHz}$ WALTZ-16 scheme, while a WURST-2 ${ }^{13} \mathrm{C}^{\prime}$ decoupling scheme is employed during acquisition to suppress ${ }^{1} \mathrm{HN}-{ }^{13} \mathrm{C}^{\prime}$ scalar couplings (bandwidth of $12 \mathrm{ppm}$, centered at $175 \mathrm{ppm}$, maximum(rms) $\mathrm{B}_{1}$ field of $\left.0.5(0.3) \mathrm{kHz}\right)$. The phase cycling used is: $\phi 1=\{y,-y\}, \quad \phi 3=2\{y\}, 2\{-y\}, \phi 4=\{y,-y\}, \phi 5=\{x\}, \phi 6=4\{x\}, 4\{-x\}, \phi 7=\{x\}$, receiver $=\{\mathrm{x},-\mathrm{x},-\mathrm{x}, \mathrm{x}\}$. The delays used are $\tau_{\mathrm{a}}=2.25 \mathrm{~ms}, \tau_{\mathrm{b}}=1 /\left(8 \mathrm{~J}_{\mathrm{NH}}\right) \sim 1.38 \mathrm{~ms}, \tau_{\mathrm{eq}}=5 \mathrm{~ms}$, $\mathrm{T}=10 \mathrm{~ms}, \mathrm{~T}_{\mathrm{N}}=13 \mathrm{~ms}$ and $\Delta=0.5 \mathrm{~ms} . N$ is any whole number. Gradient strengths $\mathrm{G} / \mathrm{cm}$ (length in ms) are: $\mathrm{g} 0=8.0(0.5), \mathrm{g} 1=4.0(0.5), \mathrm{g} 2=10.0(1.0), \mathrm{g} 3=7.0(1.0), \mathrm{g} 4=-6.0(0.6), \mathrm{g} 5=$ $-30.0(1.25), \mathrm{g} 6=4.0(0.3), \mathrm{g} 7=2.0(0.4), \mathrm{g} 8=29.6(0.125)$. Quadrature detection in the indirect dimension is obtained by recording two sets of spectra with $(\phi 7, \mathrm{~g} 5)$ and $(\phi 7+\pi,-\mathrm{g} 5)$ for each $t_{1}$ increment ${ }^{6,7}$; the phase $\phi 5$ is incremented along with the receiver by $180^{\circ}$ for each complex $t_{1}$ point $^{8}$.

\section{References}

(1) Geen, H.; Freeman, R. J. Magn. Reson. 1991, 93, 93-141.

(2) Muller, L.; Legault, P.; Pardi, A. J Am Chem Soc 1995, 117, 11043-11048.

(3) Mulder, F. A.; Spronk, C. A. E. M.; Slijper, M.; Kaptein, R.; Boelens, R. J. Biomol. NMR 1996, 8, 223-238.

(4) Gullion, T.; Baker, D. B.; Conradi, M. S. J. Magn. Reson. 1990, 89, 479484.

(5) Shaka, A. J.; Keeler, J.; Frenkiel, T.; Freeman, R. J. Magn. Reson. 1983, $52,335-338$. 
(6) Kay, L. E.; Keifer, P.; Saarinen, T. J. Am. Chem. Soc. 1992, 114, $10663-$ 10665.

(7) Schleucher, J.; Sattler, M.; Griesinger, C. Angew. Chem. Int. Ed. Engl. 1993, 32, 1489-1491.

(8) Marion, D.; Ikura, M.; Tschudin, R.; Bax, A. J. Magn. Reson. 1989, 85, 393-399. 